\title{
Erratum to: Seeing the Light: Qualitative Research, Culture, and Cognition
}

\section{Donileen Loseke $^{1}$}

Published online: 2 August 2016

(C) Springer Science+Business Media New York 2016

\section{Erratum to: Qual Sociol (2016)}

\section{DOI 10.1007/s11133-016-9338-3}

The original version of this article unfortunately contained a mistake in the 3rd book title. Eviatar Zerubavel's book should read as Hidden in Plain Sight, instead of In Plain Sight. 